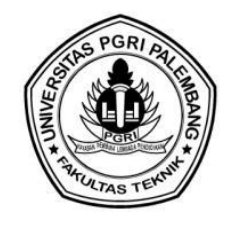

\title{
NILAI EKONOMIS PENGGUNAAN SOLAR CELL TERHADAP GENSET SEBAGAI CATU DAYA PADA BASE TRANSCIEVER STATION (BTS) TELKOMSEL DI LOKASI KELAPA DUA KABUPATEN BANYUASIN
}

\author{
Dian Eka Putra ${ }^{1}$, Higus Sapriansyah ${ }^{2}$ \\ ${ }^{1,2}$ Program Studi Teknik Elektro Fakultas Teknik Universitas Palembang \\ e-mail : dianekaputra90@gmail.com ${ }^{1}$, higus_x10@yahoo.com ${ }^{2}$
}

\begin{abstract}
ABSTRAK Telekomunikasi dan informasi merupakan bagian terpenting bagi masyarakat kota dan daerah, untuk mengcover layanan telekomunikasi khusunya didaerah pedalaman, perairan dan perbatasan yang jauh dari pusat kota, perlunya dibangun BTS (base transceiver station) sebagai akses komunikasi terhadap sinyal komunikasi dan informas. Kurangnya dan ketiadaan pasokan energi listrik dalam hal ini PT. PLN, maka Bahan Bakar Minyak jenis Solar diwilayah perairan dan pedalaman masih bisa diandalkan sebagai sumber energi lain untuk mensuplai listrik ke BTS (base transceiver station) di daerah terpencil tersebut yaitu dengan menggunakan genset sebagai catuan. Kendala dengan menggunakan genset diantaranya sulitnya transfortasi dan kelangkaan solar, harga solar yang tingggi. Untuk mengatasi masalah tersebut sebagai alternatif lain yaitu menggunakan energi surya, atau lebih dikenal dengan sebutan solar cell yang ramah lingkungan. Dengan total rata-rata cahaya matahari sebesar 4,744 KwH/m² ${ }^{2}$ sehingga kebutusan Modul PVdi BTS Kelapa Dua dibutuhkan Modul PV hubungan seri 40 buah dan Solar Charge Controller sebanyak 3 unit. Dengan menggunakan Panel Solar Cell biaya perbulan sebesar Rp. 20.000.000 tentunya lebih ekonomis, sehingga Cost saving terhadap biaya operasional genset dengan Saving cost pertahun yang didapat sebesar Rp. 160.704.750.
\end{abstract}

Kata Kunci : Kelapa Dua, Base Tranceiver Station (BTS), Genset, Solar Cell, Cost saving.

\begin{abstract}
ABSTRAC Telecommunications and information are the most important part for urban and regional communities, to cover telecommunications services especially in the remote areas, waters and borders far from the city center, the need to build a BTS (base transceiver station) as communication access to communication signals and information. Lack and lack of electricity supply in this case PT. PLN, the Solar type of fuel oil in the waters and inland areas can still be relied upon as another energy source to supply electricity to the base transceiver station in the remote area by using a generator as a supply. Constraints by using generators include the difficulty of transportation and scarcity of diesel fuel, high diesel prices. To overcome this problem as an alternative that is using solar energy, or better known as solar cells that are environmentally friendly. With a total average solar light of 4,744 $\mathrm{KwH} / \mathrm{m} 2$ so that the needs of the PV Module at BTS Kelapa Dua are required 40 series PV modules and 3 units of Solar Charge Controller. By using Solar Cell Panel a monthly fee of Rp. 20,000,000 is certainly more economical, so that the cost savings of generator operational costs with annual Saving costs obtained is Rp. 160,704,750.
\end{abstract}

Key Words : Kelapa Dua, Base Tranceiver Station (BTS), Generator electric, Solar Cell, Cost saving.

\section{PENDAHULUAN}

Kebutuhan jaringan telekomunikasi dan informasi saat ini semakin pesat perkembangannya, baik suara, data dan gambar maka perusahaan telekomunikasi memasuki lingkungan bisnis yang semakin kompetitif. Banyaknya site-site Telkomsel yang di bangun di area terpencil misal di pulau dan ketiadaan pasokan catudaya dalam hal ini PLN. maka Telkomsel berupaya untuk mencari sumber energi lain untuk mensuplai energi listrik ke BTS di daerah terpencil tersebut yaitu dengan menggunakan genset sebagai catuan. Untuk catuan menggunakan genset di site-site yang aksesnya sulit ini, terdapat kelemahan-kelemahan diantaranya kelangkaan BBM (solar), harga BBM (solar) yang tinggi selain itu untuk menggurangi ketergantungan energi fosil yang cadangannya terus menurun serta polusi yang diakibatkan pembakaran dari energi fosil [1]. Untuk menekan masalah 
tersebut maka Telkomsel pun mencoba untuk mencari alternatif lain, atau mengurangi pasokan dari PLN menuju energi yang ramah lingkungan [2], salah satunya menggunakan energi surya, atau lebih dikenal dengan sebutan solar cell (photovoltaic). Dimana dengan pemanfaatan energi matahari berarti mendukung program pemerintah yaitu semangat energi baru terbarukan (renewable spirit).

\section{TINJAUAN PUSTAKA}

\section{Pemanfaatan Energi Surya}

Energi surya sanggup menyediakan energi listrik yang dikumpulkan langsung dari cahaya matahari [4]. Indonesia mempunyai karakteristik cahaya matahari yang baik (intensitas cahaya tidak fluktuatif) dibanding tenaga angin seperti di negara-negara 4 musim, utamanya lagi sel surya relatif efisien, tidak ada pemeliharaan yang spesifik dan bisa mencapai umur yang panjang serta mempunyai keandalan yang tinggi.

Untuk memanfaatkan potensi energi surya tersebut, ada 2 (dua) macam teknologi yang sudah diterapkan, yaitu:

- Teknologi energi surya fotovoltaik, energi surya fotovoltaik digunakan untuk memenuhi kebutuhan listrik, pompa air, televisi, telekomunikasi dan informasi.

- Teknologi energi surya termal, energi surya termal pada umumnya digunakan untuk memasak (kompor surya), mengeringkan hasil pertanian (perkebunan, perikanan, kehutanan, tanaman pangan) dan memanaskan air. Photovoltaic (PV) adalah suatu sistem atau cara langsung (direct) untuk mentransfer radiasi matahari atau energi cahaya menjadi energi listrik.

\section{Sel Photovoltaic}

Sel surya sering disebut sel photovoltaic atau fotovoltan, adalah sebuah alat semikonduktor yang terdiri dari sebuah wilayah-besar diode $\mathrm{p}-\mathrm{n}$ junction, bahan semi konduktor jenis-p dibuat dari silikon yang diserap boron kepermukaannya, sedangankan bahan semi konduktor jenis-n pada permukaannya diserap phospor [5]. Sel PV adalah suatu perangkat yang mengkonversi energi radiasi matahari menjadi energi listrik. Sistem sel PV pada dasarnya terdiri dari pn junction atau ikatan antara sisi positif dan negatif di dalam sebuah sistem semikonduktor.

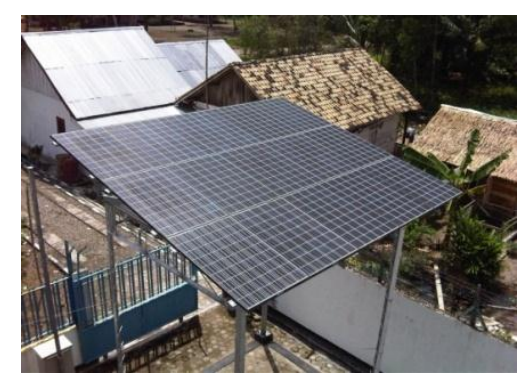

Gambar 1 Photovoltaic

\section{Sistem kerja Catuan Photovoltaic pada Base Transceiver Station (BTS)}

Prinsip kerja sistem photovoltaic pada BTS ( Base Transceiver Station) PT. Telkomsel ditunjukkan pada Gambar 2. Memperlihatkan Aliran listrik yang didapat dari panel/deretan Photovoltaic akan berupa listrik DC (Direct Current), tegangan di stabilkan oleh solar charge controller kemudian disimpan ke baterai, dan sebagian untuk mencatu beban pada Base Transceiver 
Station (BTS), Charge controller ini mengkonversi daya input dari panel PV menjadi daya output dengan menyesuaikan tegangan kerja perangkat ( $48 \mathrm{Vdc}$ )

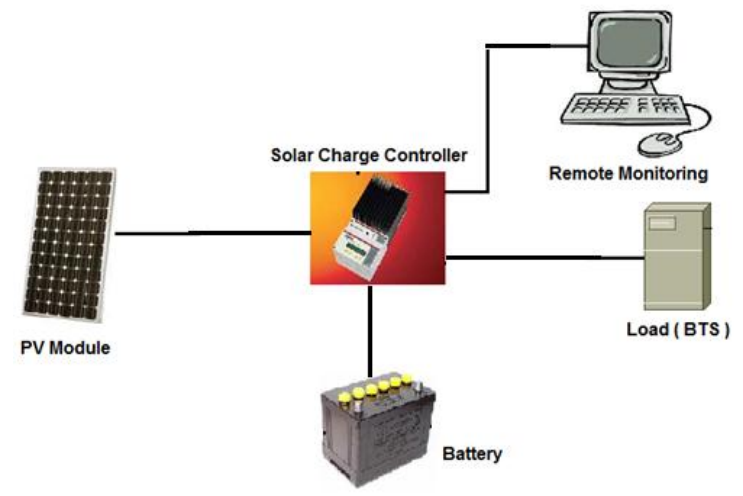

Gambar 2. Blok Diagram Sistem catuan menggunakan Photovoltaic pada perangkat BTS

\section{Solar Charge Controller}

Solar Charge Controller adalah peralatan elektronik yang digunakan untuk mengatur arus searah yang diisi ke baterai dan diambil dari baterai ke beban. Solar charge controller mengatur overcharging (kelebihan pengisian - karena baterai sudah penuh) dan kelebihan voltase dari panel surya. Kelebihan voltase dan pengisian akan mengurangi umur baterai. Solar charge controller menerapkan teknologi Pulse width modulation (PWM) untuk mengatur fungsi pengisian baterai dan pembebasan arus dari baterai ke beban. Solar panel 12 Volt umumnya memiliki tegangan output 16 - 21 Volt. Jadi tanpa solar charge controller, baterai akan rusak oleh over-charging dan ketidakstabilan tegangan [6].

Kapasitas Output Max 80 A, Maka kebutuhan Solar Charger Controller yaitu :

$$
\mathrm{Nscc}=\left(\frac{\mathrm{C}_{\mathrm{PV}} \times \mathrm{N}_{\mathrm{PV}}}{\mathrm{Vde} \times \mathrm{Cscc}}\right)+1
$$

$\begin{array}{ll}\text { Dimana : } & \\ \text { Nscc } & \text { : Jumlah kebutuhan Solar Charger Controller } \\ \text { Cpv } & : \text { kapasitas satuan Modul PV } \\ \text { Npv } & : \text { Total PV hubungan Seri } \\ \text { VDC } & : \text { Tegangan Nominal Kerja } \\ \text { Cscc } & : \text { Kapasitas Output Solar charge Controller }\end{array}$

\section{Baterai}

Baterai atau akumulator adalah sebuah sel listrik dimana didalamnya berlangsung proses elektrokimia yang reversible (dapat berbalikan) dengan efisiensinya yang tinggi. Yang dimaksud elektrokimia yang reversibel, adalah didalam baterai yang dapat berlangsung proses pengubahan energi kimia menjadi energi listrik (proses pengosongan), dan sebaliknya dari tenaga listrik menjadi tenaga kimia, pengisian kembali dengan cara regenerasi dari elektroda-elektroda yang dipakai, yaitu dengan melewatkan arus listrik dalam arah (polaritas) yang berlawanan didalam sel.

Jenis sel baterai ini disebut juga Storage Battery, adalah suatu baterai yang dapat digunakan berulang kali pada keadaan sumber listrik arus bolak-balik (AC) terganggu.Jenis sel baterai ini 
disebut juga Storage Battery, adalah suatu baterai yang dapat digunakan berulang kali pada keadaan sumber listrik arus bolak-balik (AC) terganggu.

\section{Kapasitas pengisian baterai}

Pengisian baterai atau proses charging sangat mempengaruhi kapasitas baterai pada suatu BTS. Saat awal commissioning, proses pengisian baterai harus diukur terlebih dahulu agar hasil dari proses pengisian baterai dapat berlangsung mendekati kapasitas maksimal dari baterai dan lamanya waktu yang dipakai saat proses awal charge. Kapasitas baterai di suatu BTS Telekomunikasi yaitu 2000 AH ( yang biasa digunakan untuk solar cell ). Untuk perhitungan kapasitas baterai dapat menggunakan rumus dibawah.

Kapasitas baterai $(\mathrm{AH})=\operatorname{Arus}(\mathrm{A}) \times \mathrm{Jam}$ (hour)

$\operatorname{Jam}($ hours $)=\frac{\text { Kapasitas baterai }(\mathrm{AH})}{\operatorname{Arus}(\mathrm{A})}$

\section{Generator}

Generator set adalah suatu mesin listrik yang menghasilkan energi listrik dengan medan putat atau merubah energi mekanik menjadi energi listrik Beberapa BTS Telekomunikasi menggunakan Generator KUBOTA type KJT 230 FX sebagai sumber pembangkit tenaga listrik. Type KJT 230 FX merupakan generator tipe terbuka (open type), menggunakan engine KUBOTA dengan spesifikasi engine model KUBOTA F2803 RPM (engine speed) 1500, frekuensi $50 \mathrm{~Hz}$. Tingkat kebisingan (suara) Generator terbuka (open type) KUBOTA KJT 230 FX tidak terlalu besar $\pm 80 \mathrm{db}$ (pada jarak 7 meter). Untuk menjaga kebisingan suara yag ditimbulkan dipasang dan dibangun rumah generator (Power House) dengan berperedam sehingga diharapkan hampir tidak ada suara yang terdengar dari luar lingkup BTS Telekomunikasi atau lebih kecil dari $\pm 80 \mathrm{db}$, Sedangkan pembangkit tenaga listriknya menggunakan Alternator TAIYO 4 poles (kutub) yang memiliki kapasitas 23 KVA, 3 fase + Netral dengan Daya Nyata sebesar 18400 watt, Cos $\varnothing=0,8$; Arus yang mengalir adalah sebesar 34,9 Ampere [8].

\section{Konsumsi bahan bakar Generator}

Generator yang dipakai dibeberapa BTS Telekomunikasi, menggunakan genset KUBOTA type KJT 230FX dengan menggunakan bahan bakar yang tidak terlalu boros, dan diharapkan menggunakan bahan bakar dengan kualitas yang bagus, dimana dapat mempengaruhi kinerja generator [8].

Pemakaian bahan bakar / jam :

- Beban $100 \%(18400 \mathrm{~kW})=6,5 \quad$ liter/jam

- Beban $75 \%(13800 \mathrm{~kW})=4,65$ liter/jam

- Beban $50 \%(9200 \mathrm{~kW})=3,2 \quad$ liter/jam

- Beban $25 \%(4600 \mathrm{~kW})=1,98$ liter/jam

\section{METODE PENELITIAN}




\section{Desain Penelitian}

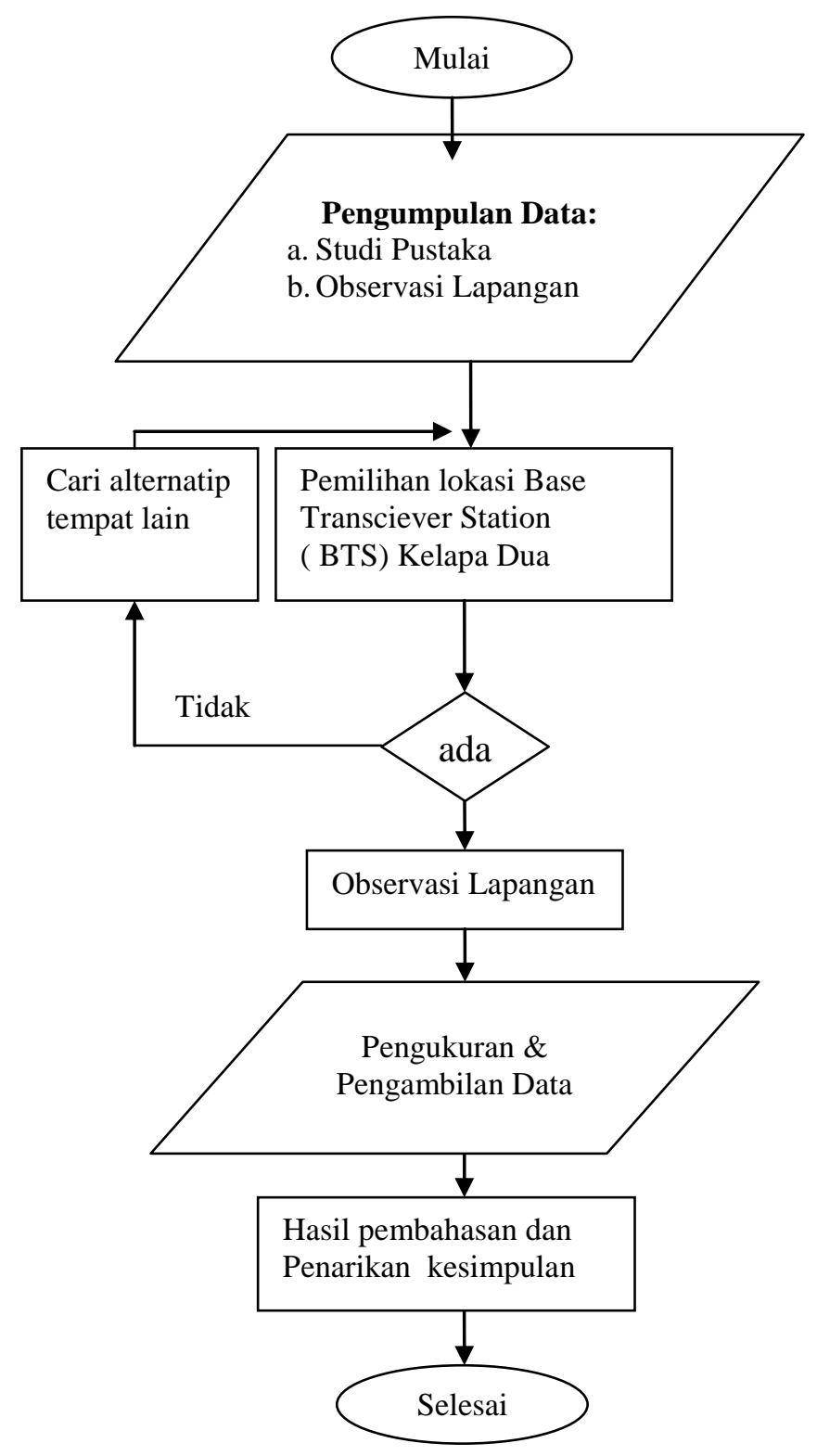

Gambar 3. Disain Penelitian “Nilai Ekonomis Penggunaan Solar Cell Terhadap Genset Pada BTS Lokasi Kelapa Dua

\section{Data Pengukuran Hasil Survei Lapangan}

Berikut hasil pengumpulan data yang didapatkan dari site Telkomsel di desa Kelapa Dua, kecamatan Pulau Rimau, kabupaten Banyuasin, Sumatera selatan.

1. Alat yang digunakan :

- GPS dan Kompas

- Solari meter atau pryanometer berfungsi untuk mengukur radiasi sinar matahari (Watt hours/m²/day) 
2. Posisi Lintang

Berada pada posisi lintang selatan/LS ( latitude ) : S $02^{\circ} 27.297^{\prime}$

Bujur Timur /BT ( longitude ) : E 105 12.609’

3. Cuaca dan Lingkungan

\begin{tabular}{|c|l|l|}
\hline No & \multicolumn{1}{|c|}{ Data } & \multicolumn{1}{c|}{ Keterangan } \\
\hline 1 & Ketinggian Site & $23 \mathrm{M} \mathrm{Dpl}$ \\
\hline 2 & Ambient Temperatur & $32^{\circ} \mathrm{C}$ \\
\hline 3 & Cuaca Pada Saat Survei & Cerah \\
\hline
\end{tabular}

\section{Data pengukuran Intensitas Cahaya Matahari}

Tabel 1. Data Pengukuran Intensitas Cahaya Matahari dan suhu

\begin{tabular}{|c|c|c|c|c|c|c|c|}
\hline \multirow[t]{2}{*}{ No } & \multirow{2}{*}{ Jam } & \multicolumn{3}{|c|}{$\begin{array}{c}\text { Intensitas Cahaya Matahari ( Solarimater ) } \\
\text { Watt hours } / \mathrm{m}^{2} / \text { day }\end{array}$} & \multicolumn{3}{|c|}{ Suhu $\left({ }^{\circ} \mathrm{C}\right)$} \\
\hline & & $14 / 03 / 2017$ & $15 / 03 / 2017$ & $16 / 03 / 2017$ & $14 / 03 / 2017$ & $15 / 03 / 2017$ & $16 / 03 / 2017$ \\
\hline 1 & 6:00 & 92 & 96 & 146 & 28,4 & 25,4 & 26 \\
\hline 2 & 7:00 & 195 & 172 & 165 & 29,3 & 27,7 & 27,3 \\
\hline 3 & 8:00 & 302 & 375 & 206 & 25,5 & 30,4 & 30,3 \\
\hline 4 & 9:00 & 221 & 584 & 254 & 28,4 & 32,5 & 32,6 \\
\hline 5 & 10:00 & 647 & 696 & 208 & 30,8 & 31,7 & 32,2 \\
\hline 6 & 11:00 & 869 & 673 & 132 & 31,7 & 33 & 32,6 \\
\hline 7 & 12:00 & 737 & 806 & 756 & 32,4 & 33,5 & 34,5 \\
\hline 8 & 13:00 & 815 & 762 & 126 & 33,5 & 33,5 & 32,3 \\
\hline 9 & 14:00 & 630 & 650 & 144 & 34,8 & 35 & 30,7 \\
\hline 10 & 15:00 & 362 & 438 & 164 & 34,3 & 35,3 & 30,6 \\
\hline 11 & 16:00 & 318 & 313 & 274 & 32,9 & 34 & 31,2 \\
\hline 12 & 17:00 & 188 & 198 & 208 & 32,9 & 34,1 & 31,4 \\
\hline 13 & 18:00 & 96 & 65 & 150 & 30,9 & 31 & 31,4 \\
\hline
\end{tabular}

\section{Data pengukuran beban}

Tabel 2. Data Pengukuran beban pada saat survei

\begin{tabular}{|c|l|l|}
\hline No & \multicolumn{1}{|c|}{ Data } & \multicolumn{1}{|c|}{ Hasil Pengukuran } \\
\hline 1 & Tegangan Baterai & 51,17 Volt \\
\hline 2 & Arus Beban & 21.6 Ampere \\
\hline 3 & Total Arus Beban & 21.6 Ampere \\
\hline 4 & Total Beban & 1105 Watt \\
\hline
\end{tabular}

\section{Data Pengisian Solar rutin pada lokasi}

Tabel 3. Pengisian Rutin Solar perbulan 


\begin{tabular}{|c|c|c|}
\hline No & Bulan & Komsumsi solar (liter ) \\
\hline 1 & Jun-16 & 2.000 \\
\hline 2 & Jul-16 & 2.000 \\
\hline 3 & Agust-16 & 2.000 \\
\hline 4 & Sep-16 & 2.000 \\
\hline 5 & Okt-16 & 1.750 \\
\hline 6 & Nop-16 & 1.750 \\
\hline 7 & Des-16 & 1.750 \\
\hline 8 & Jan-17 & 1.750 \\
\hline 9 & Feb-17 & 1.750 \\
\hline 10 & Mar-17 & 1.750 \\
\hline 11 & Apr-17 & 1.750 \\
\hline 12 & Mei-17 & 1.750 \\
\hline
\end{tabular}

\section{Spesifikasi Teknis Perangkat}

Tabel 4. Data Perangkat existing BTS

\begin{tabular}{|c|c|c|c|c|}
\hline No & Material & Merk & Type & Keterangan \\
\hline 1 & Rectifier & Hariff & APR & 48 Volt (DC) \\
\hline 2 & Genset & Kubota & KJT-23 & 23 KVA \\
\hline 3 & Baterai & Sonnenschein & $960 \mathrm{Ah}$ & 1 bank \\
\hline
\end{tabular}

Tabel 5 Data Perangkat Solar Cell

\begin{tabular}{|c|c|c|c|c|}
\hline No & Material & Merk & Type & Kapasitas \\
\hline 1 & Solarcell & Sun Earth & Mono cristal & $180 \mathrm{WP}$ (Watt Peak) \\
\hline 2 & Controller & Outback & MPPT & $80 \mathrm{Amp}$ \\
\hline 3 & Battery & FIAMM & SMG 2000/S & $2000 \mathrm{Ah}$ \\
\hline 4 & Inverter & Steca & Sinewawe & $300 \mathrm{~W}$ \\
\hline
\end{tabular}

\section{HASIL PEMBAHASAN}

\section{Perhitungan Kebutuhan Photovoltaic dan Charge Controller}

\section{Solar Irradiation}

Total Rata-rata Intensitas Cahaya Matahari per Hari

$$
\begin{aligned}
& =\quad \frac{5472+5828+2933}{3} \\
& =4744.3333 \text { watt hours } / \mathrm{m}^{2} / \text { day } \\
& =4.744 \mathrm{kwh} / \mathrm{m}^{2} / \text { day }
\end{aligned}
$$




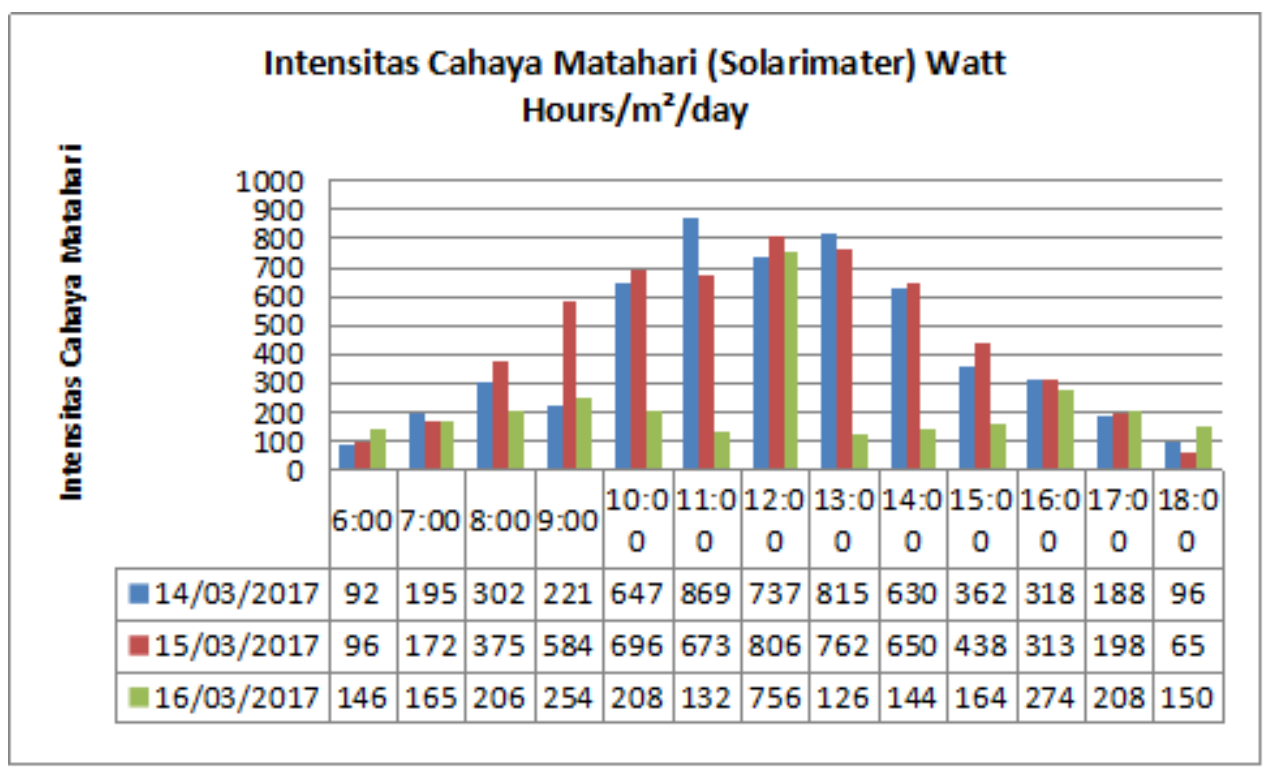

Gambar 4. Grafik Intensitas Matahari di Lokasi Kelapa Dua

Dari grafik diatas menunjukkan bahwa intensitas cahaya matahari yang tedeteksi menggunakan solarimeter bermula dari pukul 6:00 dan energi matahari tertinggi pada pukul 11:00 sampai pukul 13:00. Pada pukul 14:00 intensitas cahaya matahari mulai menurun sampai pukul 18:00 (sampai terbenamnya matahari).

\section{Beban Pemakaian Energi Listrik di BTS Kelapa Dua}

a. Peralatan AC ( 220 VAC )

\begin{tabular}{|c|c|c|c|c|c|c|}
\hline \multirow{2}{*}{ No } & \multirow{2}{*}{ Item } & \multirow{2}{*}{$\begin{array}{c}\text { Jumlah } \\
\text { (Unit) }\end{array}$} & \multicolumn{2}{|c|}{ Daya (Watt) } & Waktu & Energi \\
\cline { 4 - 5 } & & 2 & 8 & 16 & 12 & 192 \\
& & 2 & 10 & 20 & 12 & 240 \\
\hline 1 & Penerangan Umum ( a ) & 2 & Total & \\
(hann
\end{tabular}

$$
\begin{aligned}
& \text { Jumlah Beban AC ( } 220 \text { VAC ) } \\
& \text { Daya }(\text { Watt }) \quad=16+20 \\
& =36 \mathrm{Watt} \\
& =432 \mathrm{Wh} \\
& \frac{432}{95 \%}=455 \mathrm{Wh}
\end{aligned}
$$

Peralatan DC ( 48VDC )

\begin{tabular}{|c|c|c|c|c|c|c|}
\hline \multirow{2}{*}{ No } & \multirow{2}{*}{ Item } & \multirow{2}{*}{$\begin{array}{c}\text { Jumlah } \\
\text { (Unit) }\end{array}$} & \multicolumn{2}{|c|}{ Daya (Watt) } & \multirow{2}{*}{$\begin{array}{c}\text { Waktu } \\
\text { (hour) }\end{array}$} & $\begin{array}{c}\text { Energi } \\
\text { (Wh) }\end{array}$ \\
\hline 1 & & Satuan & Total & \\
& & 1 & 1105 & 1105 & 24 & 26520 \\
\hline
\end{tabular}

Total beban ekivalen DC : $26520+455=26975 \mathrm{Wh}$ 


\section{Kebutuhan Catudaya / Fotovoltaic}

Efisiensi Baterai

Load DC

Solar Irradiation

Corection, k-factor

Baterai charging efisiensi

Kebutuhan Panel fotovoltaik

$$
: 95 \%
$$$$
: \quad \frac{26975}{95 \%}: 28394 \mathrm{Wh}
$$

$$
\begin{aligned}
& : 4,7 \mathrm{kWh} / \mathrm{m}^{2} / \text { day } \\
& : 1,1 \\
& : 95 \%
\end{aligned}
$$

\section{Generator Fotovoltaik}

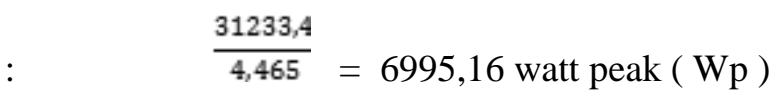

Tegangan pada daya Max dari Panel PV ( Vmp ) : : 36.2Volt

Arus pada Daya Max dari PV panel ( Imp ) : : $\quad \frac{180}{36.2}: 4,97$ A

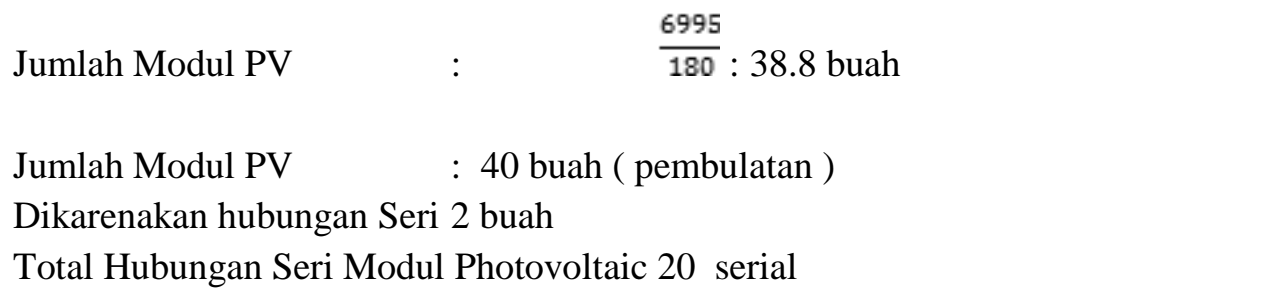

\section{Solar Charge Controller}

Kapasitas Output Max 80 A

Kebutuhan Solar Charger Controller

$$
\begin{aligned}
& \qquad \text { Nscc }=\left(\frac{C_{\text {PV } \times N_{P V}}}{\text { Vde } \times \text { Cscc }}\right)+1 \\
& =\quad\left(\frac{180 \times 40}{48 \times 90}\right)+1 \\
& =(1.875)+1 \\
& \text { Nscc }=3 \text { unit }
\end{aligned}
$$

Berdasarkan perhitungan untuk site Kelapa Dua masing-masing solar charger controller di mengontrol modul PV sebagai berikut:

- Solar Charge Controller 1 mengontrol sebanyak 14 PV modul

- Solar Charge Controller 2 mengontrol sebanyak 14 PV modul

- Solar Charge Controller 3 mengontrol sebanyak 12 PV modul 


\section{Kebutuhan Biaya Operasional Site}

1. Kebutuhan biaya operasional genset dengan sistem CDC ( sistem BTS existing site Kelapa Dua )

\begin{tabular}{|c|c|c|}
\hline No & Type Beban & $\begin{array}{l}\text { Beban } \\
\text { (watt) }\end{array}$ \\
\hline 1 & BTS & 1105 \\
\hline 2 & Charging baterai & 4336 \\
\hline \multirow[t]{2}{*}{3} & Penerangan & 40 \\
\hline & Total & 5481 \\
\hline
\end{tabular}

Perhitungan charging Baterai : ( 800 x $10 \%)$ x 54.2 volt

$$
=4336 \mathrm{Watt}
$$

Genset yang digunakan Kubota 23KVA, $(\cos \theta 0,8)=18400$ Watt

$$
\begin{aligned}
\text { Maka komsumsi solar } & =\frac{5481}{18400} \\
& =0.298 \\
& =30 \%
\end{aligned}
$$

Untuk beban $30 \%$ - 50\% kapasitas genset, ratio pemakaian solar adalah 4,5 liter/jam

Sistem CDC, genset running 12 jam per hari

Kebutuhan solar per hari $\quad=12$ jam $\times 4,5$ liter

$$
=54 \text { liter/hari }
$$

Kebutuhan solar per bulan $\quad=54$ liter/hari $\times 31$ hari

$$
=1674 \text { liter/bulan }
$$

Jika estimasi harga solar industri rata-rata tahun 2016-2017 per liter Rp. 8000, maka biaya estimasi pemakaian solar pertahun adalah 1674 liter/bulan x Rp. 8000,- x 12 bulan = Rp. 160,704.000,-

Biaya maintenance Genset pertahun Rp. 20.000.000,-

Total biaya Operasional sistem CDC Rp. 180.704.000,-

2. Kebutuhan Biaya Operasional dengan menggunakan Solar Cell

Biaya maintenance setahun Rp. 20.000.000

Maintenance Solar cell dalam setahun ada 2 kali kunjungan ke lokasi.

3. Cost saving dengan menggunakan Solar Cell

- Solar cell terhadap biaya operasional genset CDC

Saving cost pertahun yang didapat didapatkan : Rp 180.130.248 - Rp. 20.000.000 = Rp. 160.130.248,-

\section{BEP ( Break Event Point )}

Berikut Break Event Point ( BEP ) antara Solar cell dan genset :

Nilai Investasi Solar Cell Rp. 1.000.000.000,- 
Nilai Investasi Genset Rp. 583.912.000,-

Penggantian baterai per 3 tahun untuk baterai Solar cell Rp. 308.772.000,-

Penggantian baterai per 3 tahun untuk baterai Genset Rp. 283.012.000,-

Tabel 6. Perhitungan nilai BEP antara Solar cell dan Genset.

\begin{tabular}{|c|c|c|c|c|c|c|}
\hline $\begin{array}{c}\text { Tah } \\
\text { un } \\
\text { ke }\end{array}$ & \multicolumn{3}{|c|}{ Solar cell } & \multicolumn{3}{c|}{ Genset } \\
\hline & IDR & & & IDR & & \\
& $(1,000,000,000$ & & & $(583,912,000$ & & \\
0 & $.00)$ & & & $.00)$ & & IDR \\
\hline & & IDR & IDR & & $(180,704,750$ & $(764,616,750.0$ \\
1 & & $(20,000,000$. & $(1,020,000,000$ & & $.00)$ & $0)$ \\
\hline & & $00)$ & $.00)$ & & IDR & IDR \\
& & IDR & IDR & & $(180,704,750$ & $(945,321,500.0$ \\
2 & & $(20,000,000$. & $(1,040,000,000$ & & $.00)$ & $0)$ \\
\hline & & $00)$ & $.00)$ & & IDR & IDR \\
& & IDR & IDR & & $(180,704,750$ & $(1,126,026,250$ \\
3 & $6,602,625$ & $(20,000,000$. & $(1,060,000,000$ & IDR & $.00)$ \\
\hline
\end{tabular}

Dari tabel diatas nilai BEP antara sollar cell dan genset akan di dapatkan pada tahun ketiga sebesar Rp. 6.602,625 dimana untuk tahun berikutnya, tidak menggulurakan biaya banyak untuk pembelian bahan bakar minyak (HSD) Hihg Speed Diesel atau solar untuk bahan bakar Genset.

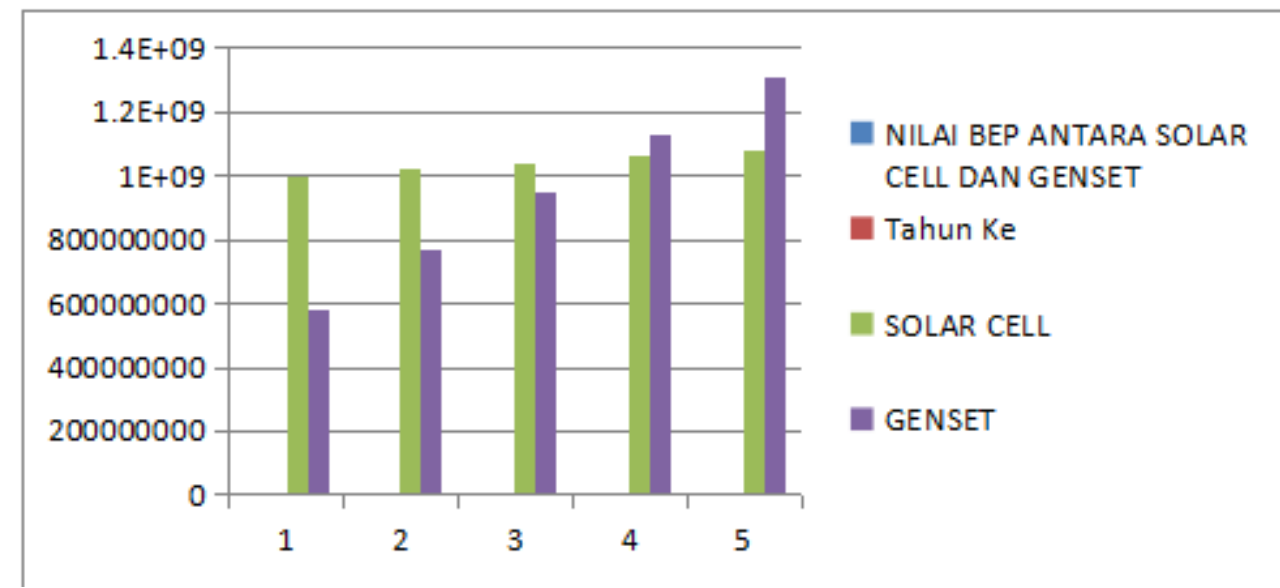

Gambar 4. Grafik BEP/Biaya Perbandingan Solar Cell dan Genset

Analisa grafik pada Gambar 4, menunjukkan bahwa investasi pada tahun pertama untuk solar cell lebih tinggi dibandingkan biaya investasi untuk genset, pada tahun kedua biaya investasi dan operasional perawatan solar cell lebih tinggi dibandingkan biaya investasi dan operasional perawatan genset, pada tahun ketiga dan keempat perbandingan biaya investasi dan operasional perawatan genset mulai mengalami penurunan dimana biaya untuk solar cell lebih murah dibandingkan biaya investasi dan operasional untuk genset.

\section{KESIMPULAN}


1. Biaya perbandingan penggunaan solar cell dan genset untuk BTS Telkomsel di Kelapa Dua lebih menguntungkan menggunakan solar cell secara ekonomis, dikarenakan opersional perbulan sebesar Rp. 20.000.000 dibandingkan dengan menggunakan genset dengan biaya operasional dan bahan bakar minyak sebesar Rp. 180.704.750.

2. Kebutuhan photovoltaic di site Kelapa Dua atau Modul PV Hubungan seri sebanyak 40 buah dan Solar Charge Controller sebanyak 3 unit.

3. Cost saving dengan menggunakan Solar Cell terhadap biaya operasional genset CDC pertahun sebesar Rp. 160.704.750.

\section{DAFTAR PUSTAKA}

[1] Junial H, Pengujian Sistem Pembangkit Listrik Tenaga Surya Solar Cell Kapasitas 50WP, 2010

[2] Badaruddin, Sugiharto. Pemanfaatan Energi Matahari sebebagai Catu Daya pada Base Tranceiver Station (BTS) Makrocell, 2011 Universitas Mercu Buana

[3]

https://scholar.google.co.id/scholar?hl=id\&as_sdt=0\%2C5\&q=B+Badaruddin $\% 2 \mathrm{C}+\mathrm{S}+$ Sugiha rto+-+2013+Pemanfaatan+energi+matahari+sebagai+catu+daya+BTS\&btnG=

[4] Chadidjah S, Wiyoto HI. Renewable Energy.2011 Genta Pustaka Jakarta

[5] Supranto. Teknologi Tenaga Surya, 2015 Global Pustaka Utama Yogyakarta

[6] http://www.tenaga-surya.com

[7] http://www.esdm.go.id/berita/artikel/56-artikel/4034-solar-cell-sumber-energi-terbarukanmasa-depan

[8] PT. United Tractors Tbk. (1993). Buku panduan Genset, Jakarta 